\section{Foliar Chlorosis in Field-Grown Red Maples}

\author{
James Altland \\ Department of Horticulture, Oregon State University, North Willamette \\ Research and Extension Center, 15210 NE Miley Rd., Aurora, OR 97002
}

Additional index words. Acer rubrum, 'Franksred', manganese, soil pH

\begin{abstract}
Franksred red maple (Acer rubrum 'Franksred') trees were sampled from nursery fields in 2003 and 2004 to determine the cause of a common foliar chlorosis. Plots in 21 and 39 different nurseries were identified in 2003 and 2004, respectively. A single plot from each nursery was sampled in June of each year, whereas two to four plots per nursery were sampled in September. Each plot consisted of 20 consecutive trees in a single row. From each plot, a foliar tissue sample was analyzed for the complete range of essential nutrients. Plant height, stem diameter, leaf chlorophyll content, and a subjective plant quality rating were also recorded. From each plot, a soil sample was collected and analyzed for $\mathrm{pH}, \mathrm{EC}$, organic matter, and a range of essential nutrients. The foliar chlorosis was determined to be incited by manganese (Mn) deficiency. Tissue Mn was highly correlated with soil $\mathrm{pH}$. Chlorotic plants were smaller with less stem diameter than nonchlorotic plants. Sufficiency ranges for tissue and soil tests were determined and are provided for red maple nursery production.
\end{abstract}

Field-grown red maple (Acer rubrum L.) often develops foliar chlorosis during mid to late summer. Although this problem is particularly common in the Pacific Northwest, it has also been observed in nursery production in other parts of the country (personal observation). The condition can be characterized initially as mild interveinal chlorosis in expanding foliage. As symptoms intensify, entire leaves turn chlorotic accompanied with interveinal necrosis. The problem has most often been associated with manganese (Mn) deficiency. Manganese deficiency has been documented in Mn-sensitive plants growing in mildly acid to alkaline soils. Oregon soils in the nursery producing region (North Willamette Valley) typically have low soil $\mathrm{pH}$ $(<5.5)$. Nonetheless, many nursery growers and crop consultants have diagnosed $\mathrm{Mn}$ deficiency with foliar tissue tests. This condition in nursery production has never been thoroughly studied.

Chlorosis in red maples incited by $\mathrm{Mn}$ deficiency has been documented in urban landscapes. Teuscher (1956) first described maple chlorosis in a trade publication. $\mathrm{He}$ indicated the chlorosis was incited by planting in heavy alkaline soils and generically suggested that the condition could be remedied by amending the soil with a conditioner and fertilizing with $\mathrm{NH}_{4} \mathrm{SO}_{4}$. Smith (1976) later stated that the problem in nursery and landscape situations is likely Mn deficiency and offered that foliar sprays of $\mathrm{Mn}\left(\mathrm{SO}_{4}\right)_{2}$ are effective for alleviating symptoms. Foliar sprays of $\mathrm{Mn}\left(\mathrm{SO}_{4}\right)_{2}$ and $\mathrm{Mn}$ chelate in

\footnotetext{
Received for publication 13 Mar. 2006. Accepted for publication 21 Apr. 2006. I thank the Oregon Association of Nurseries and the Oregon Department of Agriculture for funding this research.

E-mail james.altland@oregonstate.edu.
}

(usually February), trees are coppiced nearly to soil level. Multiple adventitious buds emerge from the remaining stub in early spring, from which one is selected and trained up a stake to develop a single leader whip with light branching. Trees are dug and sold both at the end of year 1 and some are kept and grown for a third year (year 2) into larger trees with more branching. These trees are generally grown in rows that are 1.2 to $1.5 \mathrm{~m}$ apart and spaced $0.3 \mathrm{~m}$ within the row.

The objective of this research was to identify the cause of chlorosis in franksred red maple trees throughout year 1 and 2 of production, and to develop minimum and maximum values for soil and tissue nutrient parameters that would lead to high-quality red maple trees.

\section{Materials and Methods}

2003. On 12 June 2003, plots were delineated in fields with franksred red maple (Acer rubrum) in 21 nurseries throughout the north Willamette Valley in Oregon. Soil types for each field varied but could be generalized as silt loam soils with little or no slope. Nurseries were selected based on their willingness to participate. All fields contained trees that were planted in 2002 and were in year 1 of production at the time of sampling. Each plot consisted of 20 consecutive trees within a single row (Ellis, 1975). A single plot was randomly selected in each field, avoiding only the borders of the field. From each plot, two to three recently matured leaves from each tree were pooled for a single foliar tissue sample (Mills and Jones, 1996). A soil sample was taken by collecting $\approx 12$ soil cores to a depth of $15 \mathrm{~cm}$ within the root zone ( $\approx 30 \mathrm{~cm}$ on either side of the tree row) of the 20 trees. Tissue and soil samples were analyzed for nutrients listed in Tables 1 and 2 , respectively. Trees were individually measured for height, stem diameter, chlorophyll content using a SPAD 502 Chlorophyll Meter (Minolta Camera Co., Ramsey, N.J.), and plant quality on a scale from 1 to 10 where 1 is a chlorotic tree of poor quality and 10 is a vigorous tree with dark green foliar color. Plant quality ratings were assigned solely by the author.

On 6 Sept., the same data were collected from the same plots. In addition, two or three additional plots per nursery were surveyed so that a total of 71 plots were sampled. Many fields contained regions with chlorotic plants and other regions with nonchlorotic plants. When possible, separate plots were established in chlorotic and nonchlorotic regions of the same field.

2004. Similar methods were used throughout 2004 with the following exceptions. Thirty-nine plots were delineated on 22 June 2004. Among those, 16 plots contained trees in year 1 of production, whereas the remaining 23 plots contained trees in year 2 . On 9 Sept., additional plots were again identified in each field so that a total of 90 were sampled ( 32 year 1 and 58 year 2 trees). 
Table 1. Soil variables that explain foliar Mn in field-grown franksred red maple (Acer rubrum) tissue as determined by the stepwise selection process.

\begin{tabular}{|c|c|c|c|c|c|}
\hline \multicolumn{3}{|c|}{ Samples collected, June 2003} & \multicolumn{3}{|c|}{ Samples collected, Sept. 2003} \\
\hline Parameter & Partial $\mathrm{r}^{2}$ & $P$ value & Parameter & Partial $\mathrm{r}^{2}$ & $P$ value \\
\hline$\overline{\mathrm{pH}}$ & 0.702 & $<.0001$ & $\mathrm{pH}$ & 0.5181 & $<0.0001$ \\
\hline Soil Mg & 0.068 & 0.0284 & Soil K & 0.0804 & 0.0006 \\
\hline Soil B & 0.043 & 0.0575 & Bases & 0.0464 & 0.0193 \\
\hline Soil K & 0.036 & 0.0597 & Organic matter & 0.0385 & 0.0403 \\
\hline Soil $\mathrm{NH}_{4}$ & 0.019 & 0.1494 & Soil Zn & 0.0303 & 0.0499 \\
\hline \multirow{4}{*}{ Cumulative $r^{2}$} & 0.868 & & Soil Mg & 0.0189 & 0.0692 \\
\hline & & & Soil Fe & 0.0161 & 0.1012 \\
\hline & & & Soil S & 0.0128 & 0.1267 \\
\hline & & & Cumulative $r^{2}$ & 0.7573 & \\
\hline \multicolumn{3}{|c|}{ Samples collected, June 2004} & \multicolumn{3}{|c|}{ Samples collected, Sept. 2004} \\
\hline $\mathrm{pH}$ & 0.5643 & $<.0001$ & $\mathrm{pH}$ & 0.2685 & $<0.0001$ \\
\hline Soil K & 0.0455 & 0.0478 & Soil P & 0.0597 & 0.0067 \\
\hline Soil Mg & 0.0247 & 0.1335 & Soil S & 0.0586 & 0.0052 \\
\hline Cumulative $r^{2}$ & 0.6344 & & Cumulative $r^{2}$ & 0.3868 & \\
\hline
\end{tabular}

All soil and plant analyses were done according to methods described by Gavlak et al. (2003). Soil pH and EC (electroconductivity) were measured with a $1: 2$ soil to water ratio. Soil phosphorus (P) was measured colorimetrically by Bray $\mathrm{P} 1$. Soil $\mathrm{NH}_{4}$ and $\mathrm{NO}_{3}$ were determined colorimetrically with $\mathrm{KCl}$ and $\mathrm{Ca}\left(\mathrm{SO}_{4}\right)_{2}$ extractants, respectively. Soil calcium $(\mathrm{Ca})$, magnesium $(\mathrm{Mg})$, sodium $(\mathrm{Na})$, and potassium $(\mathrm{K})$ were extracted with ammonium acetate $\left(\mathrm{CH}_{3} \mathrm{COONH}_{4}\right)$ and measured by atomic absorption and emission. Soil zinc ( $\mathrm{Zn})$, manganese $(\mathrm{Mn})$, iron $(\mathrm{Fe})$, copper $(\mathrm{Cu})$, sulfur (S), and boron (B) were extracted with diethylenetriaminepentaacetate (DTPA) sorbitol and analyzed by inductively coupled plasma emission spectrometry (ICP). Soil organic matter was determined by WalkleyBlack and a colorimetric determination. Plant total $\mathrm{N}$ was determined with an Elementar Rapid-N Total Nitrogen Analyzer (Analysensysteme $\mathrm{GmbH}$, Hanau, Germany). Plant $\mathrm{P}, \mathrm{K}, \mathrm{Ca}, \mathrm{Mg}, \mathrm{S}, \mathrm{Mn}, \mathrm{Fe}, \mathrm{B}, \mathrm{Cu}$, and $\mathrm{Zn}$ were analyzed by a wet ash digest and ICP.

Relationships between all variables were observed using scatterplot matrices. Data were analyzed with multiple regression and the stepwise selection process to develop models using the general linear model procedure in SAS (SAS Institute, Inc., Cary, N.C.). Trees were grouped according to their plant quality ratings as having a high rating $(\geq 9)$ or low rating $(\leq 8)$, and these two groups were compared for height and stem diameter using $t$ tests. Assigning a high rating to trees with plant quality ratings $\geq 9$ was decided

arbitrarily by the author based on his observations in the fields. The same guideline was used to calculate minimum and maximum tissue and soil test guidelines for high-quality franksred red maples in Tables 4 and 5 .

\section{Results}

When samples were collected in June 2003, all trees appeared vigorous with dark green foliage and had plant quality ratings of nine or higher. Despite excellent foliar color, trees differed greatly in levels of foliar Mn, from 10 to $535 \mathrm{ppm}$. A stepwise selection process revealed that soil $\mathrm{pH}$ was the most influential factor on foliar Mn (Table 1). Soil $\mathrm{pH}$ accounted for $70 \%$ of the observed variability in foliar $\mathrm{Mn}$, whereas other significant factors explained relatively little variation. Scatterplot matrices revealed identifiable patterns in the relationships among foliar Mn, soil Mn, and soil $\mathrm{pH}$. Equations were fit for each relationship (Table 2). Foliar Mn had a linear relationship with soil Mn. There was a strong exponential relationship between foliar $\mathrm{Mn}$ and soil $\mathrm{pH}$ as well as soil Mn and soil pH. Smiley et al. (1986) reported that the logarithm of foliar $\mathrm{Mn}$ in urban red maple could be described as a function of $\mathrm{pH}$ and organic matter. Our results reported in Table 2 are similar in that our exponential equations are simply the inverse of logarithmic equations as presented by Smiley et al. (1986).

By Sept. 2003, trees at some nurseries appeared healthy, whereas others were chlorotic and stunted. There was a polynomial

Table 2. Relationship among foliar Mn (f), soil Mn (s), and soil pH (p) in tissue and soil samples from field-grown franksred red maple (Acer rubrum).

\begin{tabular}{lcccc}
\hline Relationship & Year & Month & Equation & $\mathrm{r}^{2}$ \\
\hline Foliar Mn and soil Mn & 2003 & June & $\mathrm{f}=6.00 \mathrm{~s}-19.34$ & 0.578 \\
& & Sept. & $\mathrm{f}=4.38 \mathrm{~s}+13.44$ & 0.453 \\
& 2004 & June & $\mathrm{f}=5.22 \mathrm{~s}-8.37$ & 0.604 \\
& & Sept. & $\mathrm{f}=1.80 \mathrm{~s}+16.39$ & 0.181 \\
Foliar Mn and soil pH & \multirow{2}{*}{2003} & June & $\mathrm{f}=464167 \mathrm{e}^{-1.49 \mathrm{p}}$ & 0.725 \\
& & Sept. & $\mathrm{f}=262708 \mathrm{e}^{-1.52 \mathrm{p}}$ & 0.475 \\
& \multirow{2}{*}{2004} & June & $\mathrm{f}=130496 \mathrm{e}^{-1.42 \mathrm{p}}$ & 0.566 \\
& & Sept. & $\mathrm{f}=2435 \mathrm{e}^{-0.72 \mathrm{p}}$ & 0.221 \\
Soil Mn and soil pH & \multirow{2}{*}{2003} & June & $\mathrm{s}=824 \mathrm{e}^{-0.604 \mathrm{p}}$ & 0.450 \\
& & Sept. & $\mathrm{s}=944 \mathrm{e}^{-0.729 \mathrm{p}}$ & 0.521 \\
& \multirow{2}{*}{2004} & June & $\mathrm{s}=1201 \mathrm{e}^{-0.790 \mathrm{p}}$ & 0.674 \\
& & Sept. & $\mathrm{s}=801 \mathrm{e}^{-0.615 \mathrm{p}}$ & 0.516 \\
\hline
\end{tabular}

relationship between plant quality ratings and foliar Mn (Fig. 1). Plant quality increased as foliar Mn increased up to $\approx 110 \mathrm{ppm} \mathrm{Mn}$ and then decreased. More interesting was the relationship between plant quality ratings in September and foliar Mn levels the preceding June (Fig. 2). September plant quality ratings increased as June foliar Mn levels increased up to $200 \mathrm{ppm}$. Above $300 \mathrm{ppm}$ foliar Mn, plant quality began to decrease, indicating a toxic relationship from excessive $\mathrm{Mn}$. There was no relationship between June plant quality and June foliar Mn, primarily because all trees appeared healthy with dark green foliage despite variation in foliar $\mathrm{Mn}$. These data suggest that Mn deficiency occurs early in the growing season, although visual deficiency symptoms do not occur until later in the summer. Furthermore, it indicates that early-season Mn deficiency can be detected through foliar analyses long before visual symptoms manifest. SPAD readings were not correlated to plant quality ratings and were not useful in discriminating between healthy and chlorotic trees. Interveinal chlorosis incited by Mn deficiency causes green and yellow regions on the leaf, making SPAD readings erratic even with high sample numbers (30) per leaf. SPAD meters would not be a useful tool in managing chlorosis incited by Mn deficiency.

Similar to samples collected in June, variation in foliar $\mathrm{Mn}$ in September was primarily explained by soil $\mathrm{pH}$ with several other factors identified by the stepwise selection process as significant $(P \leq 0.15)$ but explaining relatively little variation (Table 1). Foliar Mn again showed a linear relationship with soil $\mathrm{Mn}$ and an exponential relationship to $\mathrm{pH}$ (Table 2).

Samples were collected in 2004 from trees in year 1 and 2 of production. Unlike 2003, plant quality ratings of trees in June ranged from poor to excellent. Plant quality was again a function of foliar $\mathrm{Mn}$, indicating a Mn deficiency. The relationship between plant quality ratings and foliar Mn was similar for both year 1 and year 2 trees (Fig. 3). Year of production was not a significant factor in the models generated. This suggests that franksred red maples respond similarly to soil $\mathrm{pH}$ conditions in both years of production, which confirms observations by growers and the author. Samples collected in June again showed that foliar Mn was primarily dependent on soil $\mathrm{pH}$. Relationships between foliar Mn, soil Mn, and soil $\mathrm{pH}$ were similar to those observed in 2003 (Table 2).

Samples collected in Sept. 2004 resulted in models with less precision. Soil pH still explained most of the variation in foliar $\mathrm{Mn}$, although the partial $\mathrm{r}^{2}$ for these samples was low $(0.2685$; Table 1$)$. Similarly, the relationship between foliar Mn and soil Mn or soil $\mathrm{pH}$ was significant but with lower $\mathrm{r}^{2}$ values (Table 2).

Neither tree height nor stem diameter was correlated to any of the soil or tissue parameters measured. However, with the exception of year 1 trees in 2004, trees with high plant quality ratings $(\geq 9)$ had greater 
Table 3. Stem diameter $(\mathrm{cm})$ and height $(\mathrm{cm})$ of franksred red maple (Acer rubrum) trees receiving high-plant quality ratings $(\geq 9)$ and low plant quality ratings $(\leq 8)$.

\begin{tabular}{|c|c|c|c|c|c|c|c|c|c|c|c|c|}
\hline \multirow[b]{3}{*}{ Foliar color rating } & \multicolumn{4}{|c|}{2003} & \multicolumn{8}{|c|}{2004} \\
\hline & \multicolumn{4}{|c|}{ Year 1 trees $^{\mathrm{z}}$} & \multicolumn{4}{|c|}{ Year 1 trees } & \multicolumn{4}{|c|}{ Year 2 trees } \\
\hline & Stem diam. & Height & Stem diam. & Height & Stem diam. & Height & Stem diam. & Height & Stem diam. & Height & Stem diam. & Height \\
\hline High rating $(\geq 9)$ & $0.81 \mathrm{a}$ & $85.7 \mathrm{a}$ & $1.53 \mathrm{a}$ & $199.4 \mathrm{a}$ & $0.88 \mathrm{a}$ & $96.1 \mathrm{a}$ & $1.63 \mathrm{a}$ & $223.6 \mathrm{a}$ & $2.32 \mathrm{a}$ & $283.4 \mathrm{a}$ & $2.71 \mathrm{a}$ & $327.2 \mathrm{a}$ \\
\hline
\end{tabular}

${ }^{2}$ Year 1 and year 2 trees are trees that are in their first and second year of shot growth after copicing, respectively.

${ }^{y}$ Means within the same column with different letters are significantly different according to Fisher protected least significant difference test $(\alpha=0.05)$.

Table 4. Nutrient ranges in tissue analysis of highquality franksred red maple (Acer rubrum)

\begin{tabular}{lccc}
\hline Nutrient & Units & Minimum & Maximum \\
\hline Nitrogen & $\%$ & 2.8 & 3.1 \\
Phosphorus & $\%$ & 0.28 & 0.38 \\
Potassium & $\%$ & 0.9 & 1.1 \\
Calcium & $\%$ & 0.45 & 0.65 \\
Magnesium & $\%$ & 0.15 & 0.20 \\
Sulfur & $\%$ & 0.18 & 0.22 \\
Iron & $\mathrm{ppm}$ & 120 & 250 \\
Manganese & $\mathrm{ppm}$ & 50 & 120 \\
Zinc & $\mathrm{ppm}$ & 45 & 56 \\
Copper & $\mathrm{ppm}$ & 6 & 8 \\
Boron & $\mathrm{ppm}$ & 13 & 19 \\
\hline
\end{tabular}

Table 5. Soil chemical properties of fields with high-quality franksred red maple (Acer rubrum).

\begin{tabular}{lccc}
\hline Nutrient & Units & Minimum & Maximum \\
\hline pH & & 5.0 & 5.8 \\
SMP pH & & 6.0 & 6.4 \\
Organic matter & $\%$ & 3.0 & 4.4 \\
Phosphorus & ppm & 50 & 100 \\
Potassium & ppm & 160 & 220 \\
Calcium & meq & 6 & 10 \\
Magnesium & meq & 1.0 & 1.6 \\
Sulfur & ppm & 9 & 18 \\
Iron & ppm & 50 & 120 \\
Manganese & ppm & 20 & 40 \\
Zinc & ppm & 1.8 & 2.7 \\
Boron & ppm & 0.2 & 0.3 \\
Copper & ppm & 1.0 & 2.1 \\
Soluble salts & mmhos & 0.2 & 0.9 \\
\hline & & &
\end{tabular}

height and stem diameter than trees with low plant quality ratings $(\leq 8)$ (Table 3 ). This indicates that $\mathrm{Mn}$ deficiency will affect growth of franksred red maple trees.

\section{Discussion}

Throughout the study, soil Mn was not selected as a variable in the stepwise selection process. Table 2 demonstrates a strong relationship between soil $\mathrm{Mn}$ and $\mathrm{pH}$, indicating that either is correlated to tissue $\mathrm{Mn}$ or tree health. That is, $\mathrm{pH}$ and soil $\mathrm{Mn}$ explain the same information so that adding soil $\mathrm{Mn}$ into the model would not have improved it and thus the stepwise process would have dropped the term. Smiley et al. (1986) reported that urban red maples in soils with greater than $70 \mathrm{ppm}$ soil Mn were healthy. Soils Mn levels in our study were far lower than this averaging only $22 \mathrm{ppm}(\mu=22, \sigma=$ 17.1); thus, the rule of thumb by Smiley would have little relevance in Oregon nursery production. Soil Mn may be informative within a soil type, but tissue Mn will be indicative of plant health anywhere.

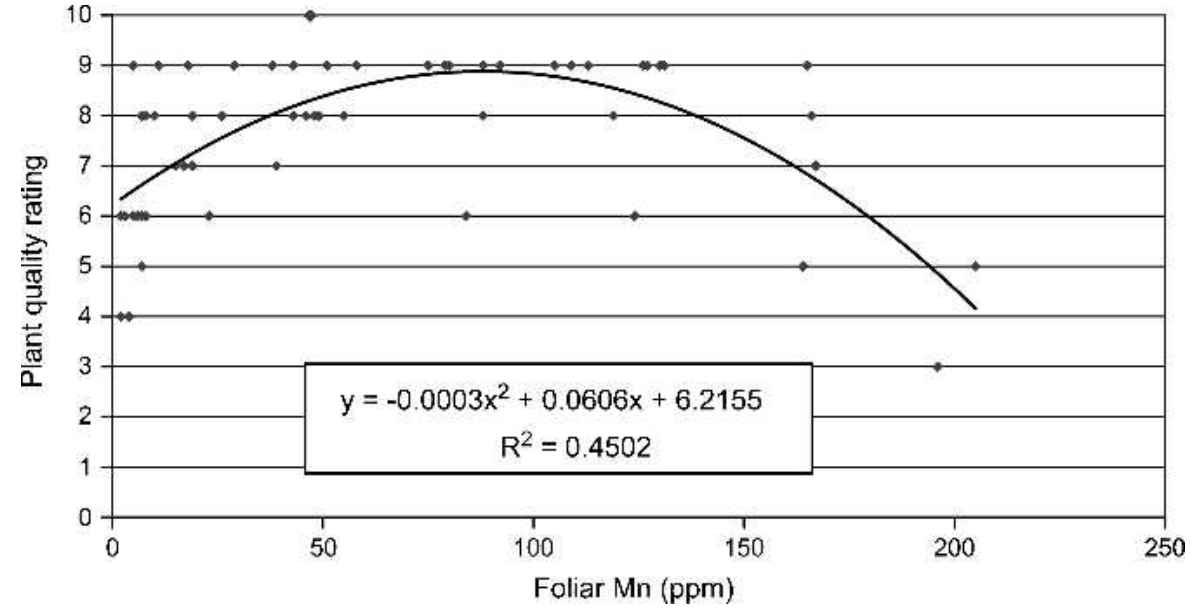

Fig. 1. Relationship between franksred red maple (Acer rubrum) foliar manganese (Mn) and plant quality ratings (where $1=$ low quality with chlorotic foliage and $10=$ high-quality tree with dark green foliar color) in Sept. 2003.

Contrary to observations by Smiley et al. (1986) in landscape trees, our data indicate soil organic matter is not related to foliar Mn in nursery production. Organic matter was only identified by stepwise selection in Sept. 2003, and even then it explains relatively little of the total variation in foliar Mn. However, soil organic matter levels in this study ranged from $1.0 \%$ to $4.1 \%$, whereas those in the Smiley study ranged from $3.0 \%$ to $9.9 \%$. The authors in the Smiley study reported that high organic matter $(>5.5 \%)$ was associated with increased chlorosis. The wider range of organic matter levels in the Smiley study probably explains why they found this variable to be significant. Christensen et al. (1950) reported that soil organic matter has relatively little influence on available Mn compared with soil $\mathrm{pH}$. Their research demonstrated that decomposition state, rather than the level of stable organic matter, increases levels of available $\mathrm{Mn}$. Furthermore, they demonstrated this effect is short-lived in neutral and alkaline soils.

Tables 4 and 5 list minimum and maximum levels of tissue and soil parameters measured, respectively. The intent is that they be used as sufficiency ranges for field production of red maples. These values differ from those suggested by Smiley et al. (1986) for urban red maples. Smiley used the mean and the mean plus one standard deviation as the minimum and maximum values, respectively. Assuming data were normally distributed, their minimum and maximum values would have been between the 50th and 68th percentiles of healthy trees according to the Empirical Rule (Freund and Wilson, 1997). This differs slightly from our approach, in which we used the 25 th and 75 th percentiles of healthy trees to determine minimum and maximum values. For red maple, Smiley et al. (1986) recommend 138 to $233 \mathrm{ppm}$ foliar $\mathrm{Mn}$ as ideal, whereas our data indicate 50 to $120 \mathrm{ppm}$. Differences in the recommended range cannot be explained solely by the different algorithms used to generate them but might be partly explained by the relative age and size of trees studied. Trees in our study had between 0.5 and $2.7 \mathrm{~cm}$ stem diameter, whereas those in the Smiley study were established landscape specimens with 5 to $30 \mathrm{~cm}$ stem diameter. Established landscape and forest trees grow slowly at a rate of 0.3 to $0.6 \mathrm{~m} /$ year (Dirr, 1998), whereas trees in this study grew up to $2.2 \mathrm{~m}$ in a single year. Aggressive growth rates, higher plant densities, and smaller root systems with access to correspondingly smaller soil volumes in nursery production may result in Mn dilution within the root zone compared with landscape trees.

Foliar Mn sprays are the most common remedy used by nursery growers to cure the chlorosis problem in field-grown red maples. However, the general opinion of nursery growers is that these sprays are time-consuming and largely ineffective (personal communication), a sentiment echoed by Kielbaso and Ottman (1976). Mn is not mobile in plants, so applying Mn to foliage only temporarily affects those parts of the plant sprayed. Repeated sprays can be made to continuously supply $\mathrm{Mn}$ to new growth. However, Mn that is only supplied to plant 


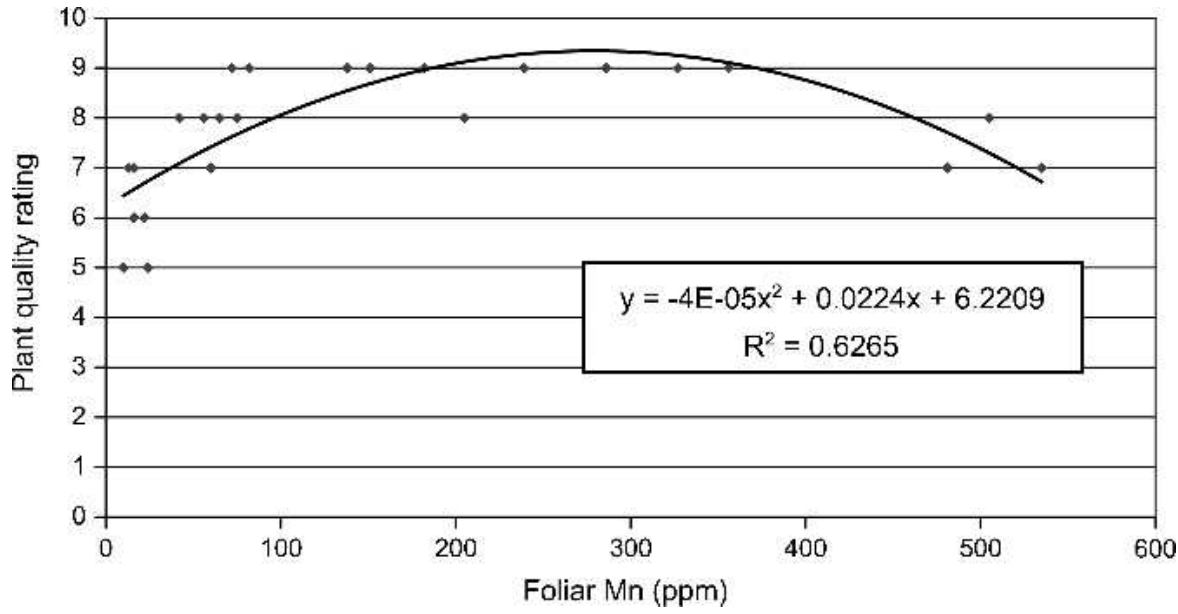

Fig. 2. Relationship between franksred red maple (Acer rubrum) foliar manganese (Mn) samples collected June 2003 and subsequent plant quality ratings (where $1=$ low quality with chlorotic foliage and $10=$ high-quality tree with dark green foliar color) recorded in Sept. 2003.

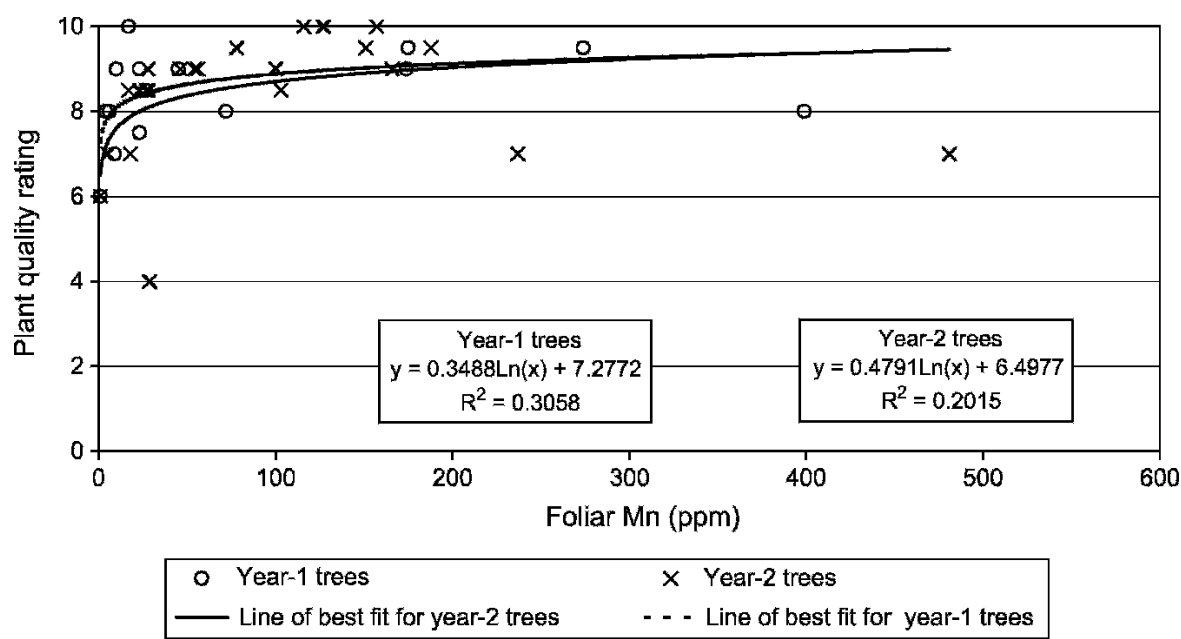

Fig. 3. Relationship between franksred red maple (Acer rubrum) foliar manganese (Mn) and plant quality ratings (where $1=$ low quality with chlorotic foliage and $10=$ high-quality tree with dark green foliar color) in year 1 and year 2 trees.

foliage will not be translocated from the foliage; thus, plant roots will be Mn-deficient despite sprays that "green up" foliage. Brown et al. (1997) found that wheat (Triticum aestivum) treated with foliar $\mathrm{Mn}$ was relieved of chlorosis symptoms; however, wheat grown in soils amended with $\mathrm{MnSO}_{4}$ had higher yields, indicating that Mn must also be made available to plant roots. The most effective way to do this is to either plant red maples in soils with sufficiently low $\mathrm{pH}$ and extractable Mn levels or amend the soil.

Smiley et al. (1986) indicated that inversion of soil layers in the Great Lakes region is likely responsible for alkaline soils and the resulting $\mathrm{Mn}$ deficiency in red collect soil samples, measure soil $\mathrm{pH}$, and then avoid planting red maples in fields with $\mathrm{pH}$ greater than 5.6. When all planting sites have high soil $\mathrm{pH}$, amending the soil with $\mathrm{S}$ to lower $\mathrm{pH}$ and adding $\mathrm{MnSO}_{4}$ to increase available $\mathrm{Mn}$ is recommended. Regionally specific lime, S, and Mn rates can be obtained from local agriculture extension offices. Management of Mn deficiency must occur before planting. Postplant remedies are less effective.

\section{Literature Cited}

Boyce, E.A. and T.D. Sydnor. 1983. Effect of varying levels of manganese and $\mathrm{pH}$ on growth of three cultivars of Acer rubrum. J. Arboric. 9:233-236.

Brown, S., J. Angle, and R. Chaney. 1997. Correction of limed-biosolid induced manganese deficiency on a long-term field experiment. J. Environ. Qual. 26:1375-1384.

Christensen, P.D., S.J. Toth, and F.E. Bear. 1950. The status of soil manganese as influenced by moisture, organic matter, and $\mathrm{pH}$. Soil Sci. Soc. Amer. Proc. 15:279-282.

Dirr, M.A. 1998. Manual of Woody Landscape Plants, Fifth Edition. Stipes, Champaign, Ill.

Ellis, R.C. 1975. Sampling deciduous broadleaved trees for the determination of leaf weight and foliar elemental concentrations. Can. J. For. Res. 5:310-317.

Freund, R.J. and W.J. Wilson. 1997. Statistical Methods, Revised Edition. Academic Press, Chestnut Hill, Mass.

Gavlak, R., D. Horneck, R. Miller, and J. KotubyAmacher. 2003. Soil, Plant, and Water Reference Methods for the Western Region, 2nd Edition. Western Rural Development Center, Corvallis, Ore.

Kielbaso, J.J. and K. Ottman. 1976. Manganese deficiency-Contributory to maple decline? J. Arboric. 2:27-32.

Messenger, S. 1986. Alkaline runoff, soil $\mathrm{pH}$ and white oak manganese deficiency. Tree Physiol. 2:317-325.

Mills, H.A. and J.B. Jones, Jr. 1996. Plant Analysis Handbook II. MicroMacro Publishing, Athens, Ga.

Russell, E.W. 1988. Soil Conditions and Plant Growth, 11th Edition. Longman Scientific \& Technical, Essex, England.

Smiley, E.T., J.B. Hart, Jr., and J.J. Kielbaso. 1985 Foliar nutrient diagnosis of urban sugar and red maples in the Great Lakes region. J. Environ. Hort. 3:104-107.

Smiley, E.T., J.J. Kielbaso, and P.V. Nguyen. 1986 Soil factors associated with manganese deficiency of urban sugar and red maples. J. Arboric. 12:169-173.

Smith, E.M. 1976. Manganese deficiencyCommon in maples. Amer. Nurs. 143:11, 131-132.

Teuscher, H. 1956. The red maple-A neglected tree. Amer. Nurs. 104:9, 58. 